\title{
Diversity and activity patterns of medium- and large-sized terrestrial mammals at the Los Tuxtlas Biosphere Reserve, México
}

\author{
Jesús Alejandro Ríos-Solis's', José Juan Flores-Martínez² ${ }^{2}$ Victor Sánchez-Cordero² and Mario C. Lavariega ${ }^{3 *}$ \\ ${ }^{1}$ Centro de Investigaciones Tropicales, Universidad Veracruzana. José María Morelos 44, 91000, Xalapa-Enríquez. Veracruz, México. \\ Email: biol-alex@hotmail.com (JAR-S). \\ ${ }^{2}$ Instituto de Biología, Universidad Nacional Autónoma de México. Aptdo. Postal 70-153, 04510. Ciudad Universitaria, Ciudad de \\ México. Email: jj@ib.unam.mx (JJF-M), victor@ib.unam.mx (VS-C). \\ ${ }^{3}$ Centro Interdisciplinario de Investigación para el Desarrollo Integral Regional Unidad Oaxaca, Instituto Politécnico Nacional. \\ Hornos 1003, 71230, Santa Cruz Xoxocotlán. Oaxaca, México. Email: mariolavnol@yahoo.com.mx (MCL). \\ * Corresponding author
}

Studies on diversity of animal communities allow determination of their species richness and composition. This information is particularly relevant to establish sound conservation programs in biosphere reserves, where human activities should be focused on the sustainable use of natural resources and ensure biodiversity protection. This study estimated the diversity and species richness and determined the species composition and activity patterns of medium- and large-sized terrestrial mammals in the Los Tuxtlas Biosphere Reserve (LTBR) located in Veracruz, Mexico. We set 18 camera traps to record medium and large-sized terrestrial mammals from August 2016 to January 2017 . We calculated the trapping rate, guilds, and activity patterns of species. Diversity was estimated with Hill numbers. We compared our estimates with other studies in tropical forest in Mexico. We obtained 308 independent captures of 13 species; Cuniculus paca and Dasyprocta mexicana were the species with the highest trapping rate. Order-0, order-1, and order-2 diversity values were 13.99, 6.50, and 4.75 effective species, respectively, which ranks LTBR the fourth-most diverse reserve of medium- and large-sized terrestrial mammals compared to six other tropical rainforest sites in southern Mexico. We recorded mammals representing five trophic guilds, of which frugivore-folivores (five species) and omnivores (three species) ranked highest. All recorded species were primarily nocturnal (six species) or diurnal (six species). Tamandua mexicana, Leopardus pardalis, L. wiedii, and Eira barbara are listed as endangered in the Mexican Official Standard Norm NOM-059-2019, and L. wiedii is listed as near threatened in the IUCN Red List of Threatened Species. We were able to record $40.6 \%$ of the terrestrial mammal species known to inhabit the LTBR. The absence of large-sized species such as large predators and herbivores was notable. Comparison of medium and large-sized mammal diversity of camera trapping studies in Mexico show that landscape degradation is impoverishing terrestrial mammal communities.

Los estudios de diversidad de las comunidades animales permiten determinar la riqueza de especies y su composición. Esta información es particularmente relevante para establecer programas de conservación en reservas de la biosfera, donde las actividades humanas deben ser enfocadas en el uso sustentable de los recursos naturales y asegurar la protección de la biodiversidad. Este estudio estimó la diversidad y riqueza de especies, y determinó la composición de especies y patrones de actividad de mamíferos terrestres de talla mediana y grande de la Reserva de la Biosfera Los Tuxtlas (RBLT), en Veracruz, México. Entre agosto de 2016 y enero de 2017, se colocaron 18 trampas cámara para registrar mamíferos terrestres de talla mediana y grande. Calculamos la tasa de captura, gremios, y patrones de actividad de las especies. La diversidad la estimamos con los números de Hill. Se compararon los valores estimados con estudios en otros bosques tropicales húmedos de México. Se registraron 308 capturas independientes de 13 especies; Cuniculus paca y Dasyprocta mexicana fueron las especies con la tasa de captura más alta. Los valores de diversidad del orden-0, orden-1, y orden-2 fueron 13.99, 6.50, y 4.75 especies efectivas, respectivamente, los cuales colocan a la RBLT en el cuarto lugar en diversidad de mamíferos terrestres medianos y grandes, de seis bosques tropicales húmedos del sur de México. Se registraron cinco gremios, de los cuales el de los frugívoros-folívoros (cinco especies) y el de los omnívoros (tres especies) fueron los mejor representados. Las especies fueron principalmente nocturnas (seis especies) y diurnas (seis especies). Tamandua mexicana, Leopardus pardalis, L. wiedii y Eira barbara están enlistadas como en peligro de extinción en la Norma Oficial Mexicana NOM-059-2019 y, L. wiedii, está enlistada como cercanamente amenazada en la Lista Roja de Especies Amenazadas de la UICN. Se detectaron el $40.6 \%$ de las especies de mamíferos terrestres conocidos que potencialmente habitan en la RBLT. La ausencia de especies de talla grande, como grandes depredadores y herbívoros, fue notable. La comparación de la diversidad de mamíferos terrestres de talla mediana y grande de estudios con foto-trampeo en México, muestran que la degradación del paisaje está empobreciendo estas comunidades.

Keywords: Camera traps; community-based monitoring; defaunation; Hill numbers; species richness; trapping rate.

(c) 2021 Asociación Mexicana de Mastozoología, www.mastozoologiamexicana.org

\section{Introduction}

Studies on the diversity of animal communities provide a direct method to determine their species richness and composition, and the relative abundance of individual species (Magurran 2004; Robinson 1999; Sigel et al. 2006; Laurance et al. 2008). This information is of particular relevance in protected areas such as biosphere reserves, to establish sound conservation and management programs involving their inhabitants, where human activities should be focused on a sustainable use of natural resources and ensure biodiversity protection (Sigel et al. 2006; Negrões et al. 2011).

Medium-and large-sized terrestrial mammals frequently are used, for various reasons, as a faunistic group to identify potential impacts of habitat loss and fragmentation due to human-induced activities on ecosystems ( $\mathrm{O}^{\prime}$ Connell et al. 2010; Monroy-Vilchis et al. 2011; Canale et al. 2012). First, 
this group of terrestrial mammals occupies a high trophic level in food webs and, thus, their occurrence and abundance have cascade effects at lower trophic levels (Roemer et al. 2009). They also comprise a wide range of guilds and have diverse spatial and habitat requirements, and include both generalist and specialist species. This wide range of ecological characteristics likely results in a differential species-by-species response to the impact of habitat loss and fragmentation. For example, species with large size, habitat and diet specialists, and/or requiring large home ranges are more likely to experience local population extirpations than medium-sized species, and/or habitat and diet generalist species, and those holding smaller home ranges (Ferguson and Larivière 2002; Michalski and Peres 2007).

The Mexican State of Veracruz is well-recognized for its high biodiversity, species richness, and endemicity (González-Christen and Delfín-Alfonso 2016). It is the thirdrichest State in the country in number of terrestrial vertebrate species, only after the States of Oaxaca and Chiapas (Flores-Villela and García-Vázquez 2014; Navarro-Sigüenza et al. 2014; Parra-Olea et al. 2014; Sánchez-Cordero et al. 2014). A total of 195 terrestrial mammal species - $39.3 \%$ of the species known to inhabit Mexico - have been recorded in Veracruz to date (Ramírez-Pulido et al. 2014). However, about one-third (53 species; $27 \%$ ) of those species currently are listed in some category of risk in the Mexican Official Standard Norm NOM-059-2010 (GonzálezChristen and Delfín-Alfonso 2016).

Veracruz has suffered from rampant deforestation over the past decades, causing wide areas of habitat loss and fragmentation as the land is transformed for agricultural and livestock uses (Challenger and Dirzo 2009; Mas et al. 2009; Sánchez-Colón et al. 2009; Gerez-Fernández and Pineda-López 2011; Von Thaden et al. 2020). According to the Instituto Nacional de Estadística y Geografia (INEGI 2015), only $18 \%$ of the State remains covered by natural vegetation, and $64 \%$ is secondary vegetation. The tropical rainforest is an ecosystem that particularly has been affected by deforestation, with less than $15 \%$ of its original area remaining (Velázquez et al. 2002). For example, what once was an almost continuous area across the lowlands of Veracruz, large fragments of tropical rainforest can be found only in a few regions such as the Sierra de Zongolica mountain range, Las Choapas, Uxpanapa, and Los Tuxtlas (GerezFernández and Pineda-López 2011). Los Tuxtlas region harbors the northernmost remnants of tropical rainforest in the Americas (Morrone 2019), and has been decreed as a biosphere reserve in the national system of protected areas to conserve biodiversity (Comisión Nacional de Áreas Naturales Protegidas; CONANP 2006).

Los Tuxtlas Biosphere Reserve (LTBR) possesses an exceptional biodiversity including a high species richness and endemicity, and includes a significant human population distributed in many widespread and small, local communities (González-Soriano et al. 1997; CONANP 2006; GutiérrezGarcía and Ricker 2011). Furthermore, this region shows a high degree of habitat loss and fragmentation; over $50 \%$ of the original vegetation has been transformed into areas for agriculture and livestock (Vega-Vela et al. 2018; Von Thaden et al. 2020). Habitat loss and fragmentation at large scales have profound negative effects on species richness and composition of terrestrial mammals in the tropical forests of southern Mexico. For instance, in Los Tuxtlas, Estrada et al. (1994) found that of 30 species detected in undisturbed forests, only 14 were found in disturbed forests, 11 in old second growths, and eight in young second-growth habitats. They also observed a negative relationship of species richness and individual species abundance concerning isolating distance of fragments, and a lower species richness in smaller fragments. Larger species were found only in larger fragments and in undisturbed forests. In the Lacandona tropical forest, Chiapas, Garmendia et al. (2013) found similar results; species richness increased with larger remnant habitat fragments, and large-sized species were only present in continuous forests.

At the landscape level, studies provide insights on the local conservation status of species, and provide a better understanding of patterns on the local effects of habitat loss and fragmentation on biodiversity (Bogoni et al. 2020). In this context, it is important to gather information on the status of the terrestrial mammal community to establish adequate conservation and management programs to promote a sustainable use of the natural resources by local inhabitants and to ensure the protection of biodiversity. This study aims to estimate the diversity, species richness, and composition of medium- and large-sized terrestrial mammals at the LTBR, and describe their activity patterns in a mosaic of forests and secondary vegetation landscapes (locally known as acahuales).

\section{Material and Methods}

Study Area. The LTBR is part of the Los Tuxtlas region, located in the central-southern part of Veracruz, Mexico $\left(18^{\circ} 13^{\prime}\right.$ and $18^{\circ} 42^{\prime} \mathrm{N},-94^{\circ} 40^{\prime}$ and $\left.-95^{\circ} 20^{\prime} \mathrm{W}\right)$ with an area of $1,551 \mathrm{~km}^{2}$ (Figure 1). A distinctive feature of the Los Tuxtlas region is its extensive fluvial network, part of the drainage basin of the Papaloapan River, which is one of the major basins in the country in terms of water volume discharged into the Gulf of Mexico (SEMARNAT 2016). From a biogeographic perspective, Los Tuxtlas is regarded as a district of the Veracruzana physiographic province, which stands out for its ecological and physiographic identity as well as for being an area of high endemism dominated by tropical rainforest, and it is related to the Chiapas Highlands physiographic province (Morrone 2019). The prevailing climate belongs to the group of warm and semi-warm, according to the Köppen classification (García 2004); annual precipitation ranges from 1,500 to $4,500 \mathrm{~mm}$, and temperature ranges from 21.5 to $27.3^{\circ} \mathrm{C}$. Nine different vegetation types have been reported for the region, the most important being high- and medium-stature tropical rainforest, low-stature seasonally-flooded tropical rainfor- 
est forest, and mountain cloud forest (Von Thaden et al. (2020). According to Von Thaden et al. (2020), $50 \%$ of the LTBR is covered by pastures, $20 \%$ by tropical rainforest, $9 \%$ by riparian vegetation, $7 \%$ by mountain cloud forest, $4.5 \%$ by secondary vegetation derived from tropical rainforest, $4.5 \%$ by agriculture, and other land-uses, each covering less than $5 \%$ of the area.

Sampling protocol. We followed the community-based framework for camera-trap studies proposed by Lavariega et al. (2020). This approach involves engaging a number of actors, including government staff of the protectedarea system, community monitors (local people previously trained in biodiversity studies), non-governmental organizations, and academic institutions, aiming to exchange knowledge and experience, make decisions on sampling design, participate in data collection, and discuss and communicate the results.

Maps on vegetation and land use, roads, human settlements, rivers, and elevation were used to select and locate sampling sites. A grid of 40 contiguous $9-\mathrm{km}^{2}$ cells was overlaid on maps using the geographic information system Quantum Geographic Informatic Systems (QGIS Development Team 2017). This cell size corresponded to the minimum home range size reported for jaguars in Mexico (Ceballos et al. 2016) - the largest species known to (historically) occur in the region (González-Christen and DelfínAlfonso 2016). A total of 18 grid cells were selected within the reserve and its surrounding area of influence based on vegetation cover, accessibility, the experience of community monitors, and security.

One camera-trap station was set on each cell between late August and early December 2016. Each camera was securely fastened to a tree trunk $40 \mathrm{~cm}$ above the ground and approximately 1-2 $\mathrm{m}$ from an animal trail. Cameras were set to operate 24 hours a day, shooting photographs every $30 \mathrm{~s}$. The geographic location (datum WGS84) and elevation of each camera trap were recorded using a GPS (Figure 1). Each camera trap was tested before leaving the site to confirm its correct operation. All camera traps were checked 30 days after installation to download photographs, replace batteries, and monitor operating conditions. Cameras operated for 62.5 days on average (minimum 58 and maximum 85 days) and were removed between late October 2016 and late January 2017.

Statistical analyses. The sampling effort was calculated as the total number of camera-traps set multiplied by the number of days sampled. All photographs of a given species captured within a 24-hour cycle were regarded as a single independent capture. In those cases where groups of individuals were photographed, each individual was counted as an independent capture (Pérez-Irineo and SantosMoreno 2010). Community diversity was evaluated according to four components: species richness, camera-trapping rate, diversity indices, and trophic guilds (Magurran 2004). Species richness was estimated as the total number of species recorded by camera-traps. The camera-trapping rate was estimated as the total number of independent captures divided by the sampling effort, and multiplied by 100 (Jenks et al. 2011; Lira-Torres and Briones-Salas 2012).

We evaluated diversity in terms of Hill numbers, ${ }^{9} D=$ $\left.\left(\Sigma_{(i=1)}^{S} p_{i}^{q}\right)^{1(1-q)}\right)$, where: $S$ is the number of species, $p_{i}$ is the abundance of the $i^{\text {th }}$ species, and $q$ is the order of diversity. The value of $q$ controls the degree of influence of rare or common species on diversity (Jost 2006; Jost and GonzálezOreja 2012). Order-0 diversity is the effective species richness, regardless of the abundance of individual species; order-1 diversity takes into account the relative abundance of species without favoring any, and is equivalent to the exponential of Shannon's diversity index; order-2 diversity gives a greater weight to the most common species, and numerically is equivalent to the inverse of Simpson concentration index (Jost 2006; Gotelli and Chao 2013; Chao and Jost 2015). Diversity values can be interpreted as "effective number of species" or "equivalent species", and denoted the number of equally common or equally abundant species composing a hypothetical community (Jost 2006; Jost and González-Oreja 2012). Diversity indices were computed using the software SPADE (Chao et al. 2016). Order-0 diversity indices were calculated using the abundance-based coverage estimator; the maximum likelihood estimation was used for order-1 and order- 2 diversity indices. The respective $95 \%$ confidence intervals were constructed with the same software using the bootstrap method with 1,000 iterations, to evaluate the sampling uncertainty and allow comparisons between areas (see below).

All species recorded were assigned to the trophic categories considered by Pérez-Irineo and Santos-Moreno (2013) and González-Salazar et al. (2014), as follows: 1) Small-prey carnivores, species consuming prey smaller than $1 \mathrm{~kg}$ in body size; 2) Small- and medium-sized-prey carnivores, consuming prey whose body size ranges between 1 and $10 \mathrm{~kg}$; 3) Large-prey carnivores, consuming prey larger than $10 \mathrm{~kg}$; 4) Frugivores, consuming mostly fruits; 5) Folivores, consuming mostly leaves; 6) Granivores, consuming mostly seeds; 7) Scavengers, consuming mostly carrion; 8) Insectivores, consuming mostly insects; and 9) omnivores, species that show no preference for a particular food type.

The activity patterns of each species were classified according to the categories proposed by Cortés-Marcial and Briones-Salas (2014) and Buenrostro et al. (2020): diurnal (8:00 h-18:00 h), crepuscular (6:00 h-8:00 h and 18:00 h-20:00 h), and nocturnal (20:00 h-6:00 h). We quantified the daily activity levels of species with at least 18 independent captures, by fitting a smoothed circular Kernel density model (Meredith 2018; Sollmann 2018), using the package Overlap (Meredith 2018). Trapping rates were standardized by rescaling them to the total number of records, divided by sampling effort and multiplied by 100 . Systematics and taxonomy followed Ramírez-Pulido et al. (2014). All photographs recorded were deposited in the official archives of the LTBR office at the Comisión Nacional de Áreas Naturales Protegidas. 


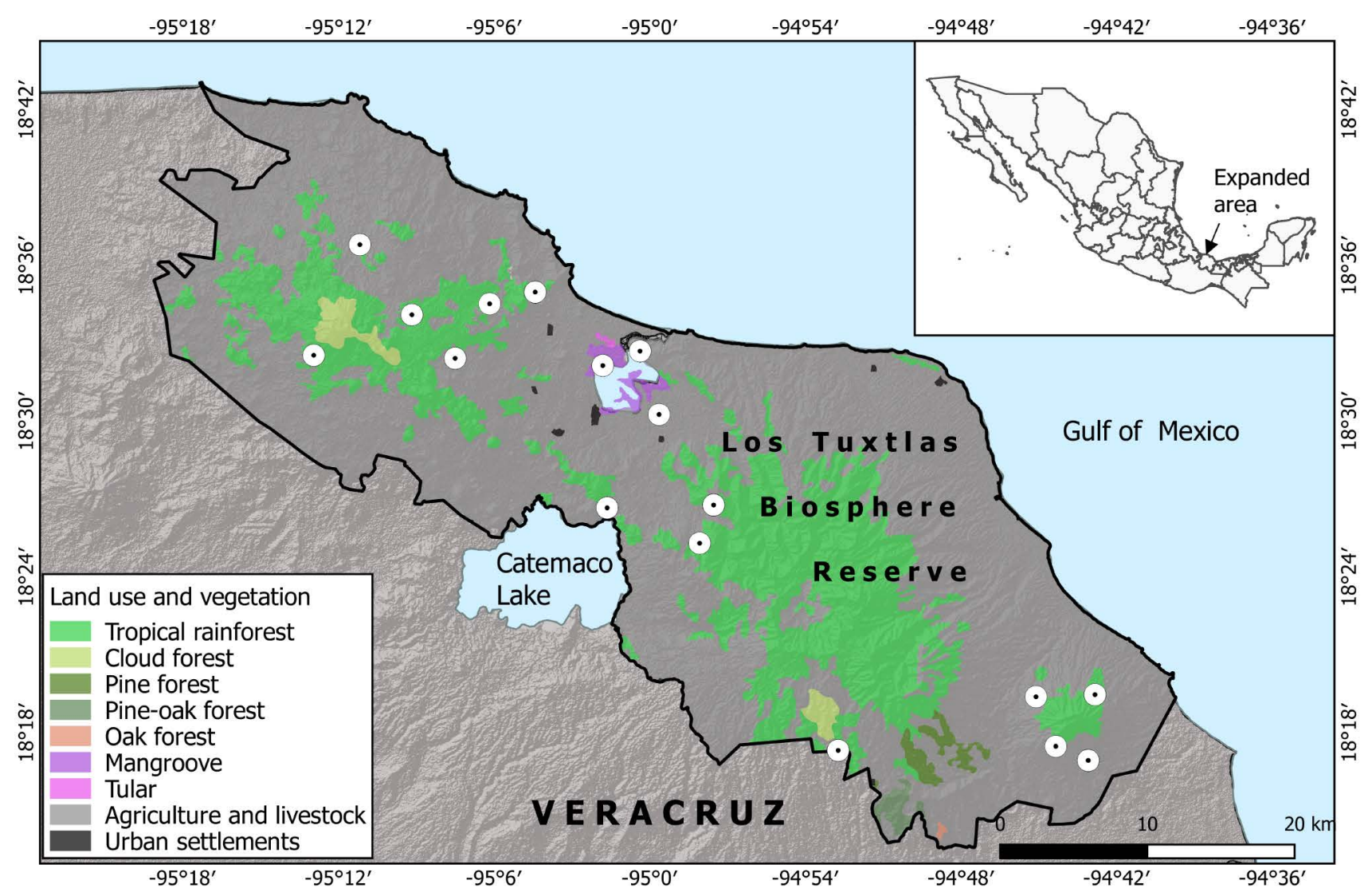

Figure 1. Location, land use, and vegetation types in Los Tuxtlas Biosphere Reserve (LTBR), Veracruz. The locations of the camera-trapping stations set for recording medium- and large-sized terrestrial mammals are indicated by white circles.

The diversity-index and trapping-rate values obtained for LTBR were compared with those obtained in other camera-trap studies conducted in tropical forests in southeast Mexico. Studies were selected based on the following criteria: use of digital camera traps, individuals of the same species recorded with a separation of at least $24 \mathrm{~h}$ were regarded as separate captures, the study provided information for the dry season of the year, and no baits were used for sampling. The selected studies were from: 1) Los Chimalapas, Oaxaca, 3,240 camera-days during the dry season in tropical rainforests and acahuales (Lira-Torres and Briones-Salas 2011); 2) Tolistoque, Oaxaca, 2,592 camera-days during the dry season in tropical dry forest (Cortés-Marcial and Briones-Salas 2014); 3) Los Petenes, Yucatán, 1,884 camera-days during the dry season in peten vegetation within mangrove swamps (Hernández-Pérez et al. 2015); 4) La Encrucijada, Chiapas, 2,700 camera-days during the dry season in mangrove swamps, medium-stature sub-evergreen tropical rainforests, tropical dry forests, zapotonales (Pachira aquatica swamps), and tulares (Typha dominguensis swamps; Hernández-Hernández et al. 2018); and 5) El Gavilán, Oaxaca, 7,235 camera-days, in tropical dry forest (Buenrostro et al. 2020). All the independent captures of species recorded during the dry season of the year in each of these studies were compiled. These data were used to calculate the Hill numbers and the respective $95 \%$ confidence intervals $(C l)$ with the software SPADE, to identify significant dif- ferences between the studies. The trapping rates of species recorded in at least three of the camera-trap study sites from southeast Mexico were compared.

\section{Results}

A total sampling effort of 1,110 camera-days yielded 308 independent captures of medium- and large-sized terrestrial mammals. Species richness included 13 species in 12 genera, 12 families, and six orders (Table 1). Two species accounted for $60 \%$ of all records: Cuniculus paca and Dasyprocta mexicana, with 105 and 81 records, respectively. In contrast, seven other species were recorded less than ten times each (Didelphis spp., Sciurus aureogaster, Eira barbara, Canis latrans, Mazama temama, and Tamandua mexicana). Leopardus pardalis and L. wiedii were recorded only once. Most (65\% of total) captures were in the medium-stature tropical rainforest, $27 \%$ in high-stature tropical forest, and $8 \%$ in acahuales. C. latrans, E. barbara, L. pardalis, and S. aureogaster were recorded only in medium-stature tropical rainforests, $L$. wiedii was recorded only in acahuales, and the remaining species were recorded in at least two different vegetation types (Table 1). C. paca and $D$. mexicana had the highest trapping rates, with 9.46 and 7.30, respectively. Three other species (Nasua narica, Dicotyles angulatus, and Dasypus novemcinctus) showed intermediate trapping rates (1.71 - 3.06), and five others had low values $(<$ $1.0)$ ) L. pardalis and $L$. wiedii occurred very rarely and had the lowest trapping rates (Figure 2). 


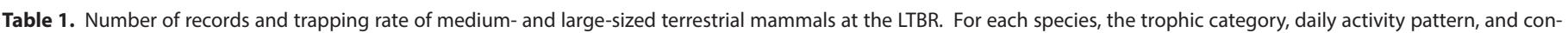

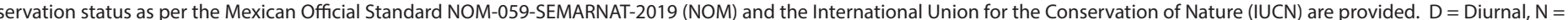
Nocturnal, $\mathrm{C}=$ Crepuscular, $\mathrm{PE}=$ Endangered, NT $=$ Near Threatened, and DD $=$ Data Deficient.

\begin{tabular}{|c|c|c|c|c|c|c|c|c|}
\hline Order & Family & Species & Trophic guild & D & C & $\mathbf{N}$ & NOM & IUCN \\
\hline Didelphimorphia & Didelphidae & Didelphis spp. & Omnivore & & 37.5 & 62.5 & & \\
\hline Cingulata & Dasypodidae & Dasypus novemcinctus & Insectivore & & 26.3 & 73.7 & & \\
\hline Pilosa & Myrmecophagidae & Tamandua mexicana & Insectivore & 33.3 & & 66.7 & PE & \\
\hline \multirow[t]{3}{*}{ Rodentia } & Sciuridae & Sciurus aureogaster & Frugivore-Folivore & 37.5 & 62.5 & & & \\
\hline & Agutidae & Dasyprocta mexicana & Frugivore-Folivore & 67.1 & 25.6 & 7.3 & & \\
\hline & Cuniculidae & Cuniculus paca & Frugivore-Folivore & 7.6 & 17.1 & 75.2 & & \\
\hline \multirow[t]{5}{*}{ Carnivora } & Felidae & Leopardus pardalis & Carnivore of small and medium-sized vertebrates & & & 100.0 & PE & \\
\hline & & Leopardus wiedii & Carnivore of small-sized vertebrates & & & 100.0 & $\mathrm{PE}$ & NT \\
\hline & Canidae & Canis latrans & Carnivore of small and medium-sized vertebrates & 83.3 & 16.7 & & & \\
\hline & Mustelidae & Eira barbara & Omnivore & 57.1 & 42.9 & & $\mathrm{PE}$ & \\
\hline & Procyonidae & Nasua narica & Omnivore & 63.6 & 15.2 & 21.2 & & \\
\hline \multirow[t]{2}{*}{ Artiodactyla } & Tayassuidae & Dicotyles angulatus & Frugivore-Folivore & 48.3 & 17.2 & 34.5 & & \\
\hline & Cervidae & Mazama temama & Frugivore-Folivore & 66.7 & 16.7 & 16.7 & & DD \\
\hline
\end{tabular}

Trophic guilds. We identified five trophic guilds: smallsized prey carnivores, small and medium-sized prey carnivores, frugivore-folivores, insectivores, and omnivores. The frugivore-folivore guild was the most species-rich, with five species, followed by the omnivore guild with three species (Table 1).

Activity patterns. Dasyprocta mexicana, C. latrans, and $M$. americana were largely diurnal ( $>66.6 \%$ of the records in this category), while $D$. novemcinctus, $T$. mexicana, C. paca, $L$. pardalis, and $L$. wiedii, were primarily nocturnal (> $66.6 \%$ of the records in this category). Other species, such as $D$. marsupialis, were mainly nocturnal $(62.5 \%)$ but exhibited crepuscular activity (37.5\%). S. aureogaster was crepuscular (62.5\%) and diurnal (37.5\%). E. barbara was diurnal and crepuscular. Records of N. narica and D. angulatus were mostly diurnal, but also showed crepuscular and nocturnal activities (Table 1).

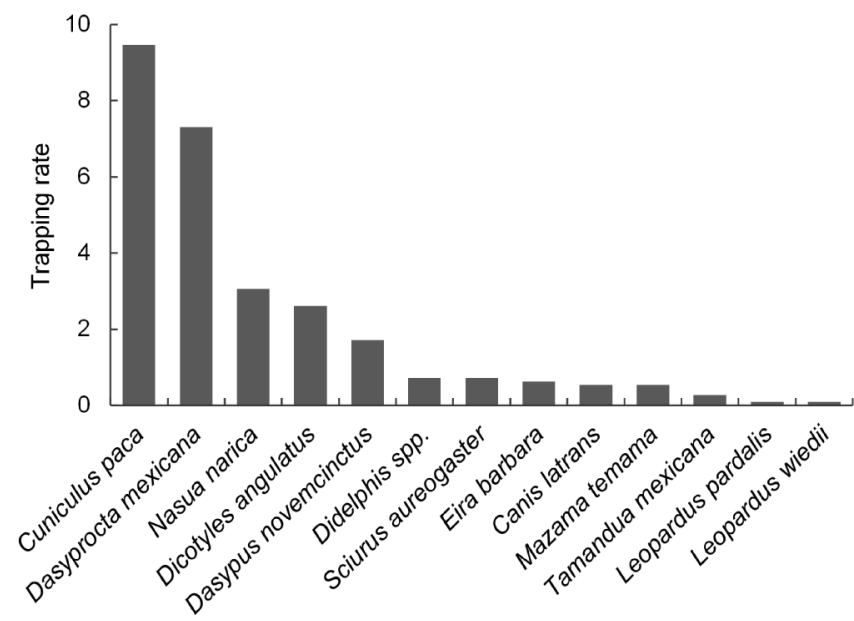

Figure 2. Trapping rates of medium- and large-sized terrestrial mammals recorded from camera-traps at the LTBR, calculated with the number of independent records, divided by the sampling effort and multiplied by 100 . See Methods for details.
Five species had sufficient records ( $>18$ ) to fit Kernel models and describe their daily activity patterns. D. mexicana and $N$. narica were typically diurnal, with two activity peaks, one before noon and the second, most active period, at dusk. D. angulatus showed both diurnal and crepuscular activity, but its activity peaked before noon. C. paca and $D$. novemcinctus exhibited crepuscular and nocturnal activity; their activity peaked early in the evening and showed a secondary peak before dawn (Figure 3A-E). As for the other species, C. latrans, E. barbara, and S. aureogaster were recorded mainly in the daytime and, less frequently, at crepuscular or nocturnal periods; Didelphis spp. and D. novemcinctus were nocturnal and crepuscular, and T. mexicana was nocturnal and diurnal. L. pardalis and L. wiedii were both recorded only at night.

The highest species richness was recorded in Los Chimalapas (21 species) and La Encrucijada (18 species); intermediate species richness was recorded in Tolistoque (14 species) and Los Petenes and LTBR (13 species each). The lowest species richness was recorded at El Gavilán (Figure 4). Order-0 diversity was 13.80 effective species (Cl: 13.10 to 22.70 ), order-1 diversity was 6.47 (Cl: 5.79 to 7.15$)$, and order-2 diversity was 4.69 (Cl: 4.15 to 5.24$)$. Order-0 diversity in the other study sites conducted in the dry season in tropical forests from southeastern Mexico was highest in Tolistoque (25.6), followed by Los Chimalapas (22.8), and La Encrucijada (20.0). Except for El Gavilán, where the lowest order-0 diversity (10.00) was recorded, the $95 \%$ confidence intervals of the other localities overlap with each other. In contrast, when the relative species abundance was taken into account, El Gavilán showed the highest diversity value, with 9.39 effective species, followed by Los Chimalapas (8.22), La Encrucijada (7.97), and Tolistoque (6.22), and most of these differences were statistically significant, except for Los Chimalapas vs. La Encrucijada, and LTBR vs. Tolistoque, 

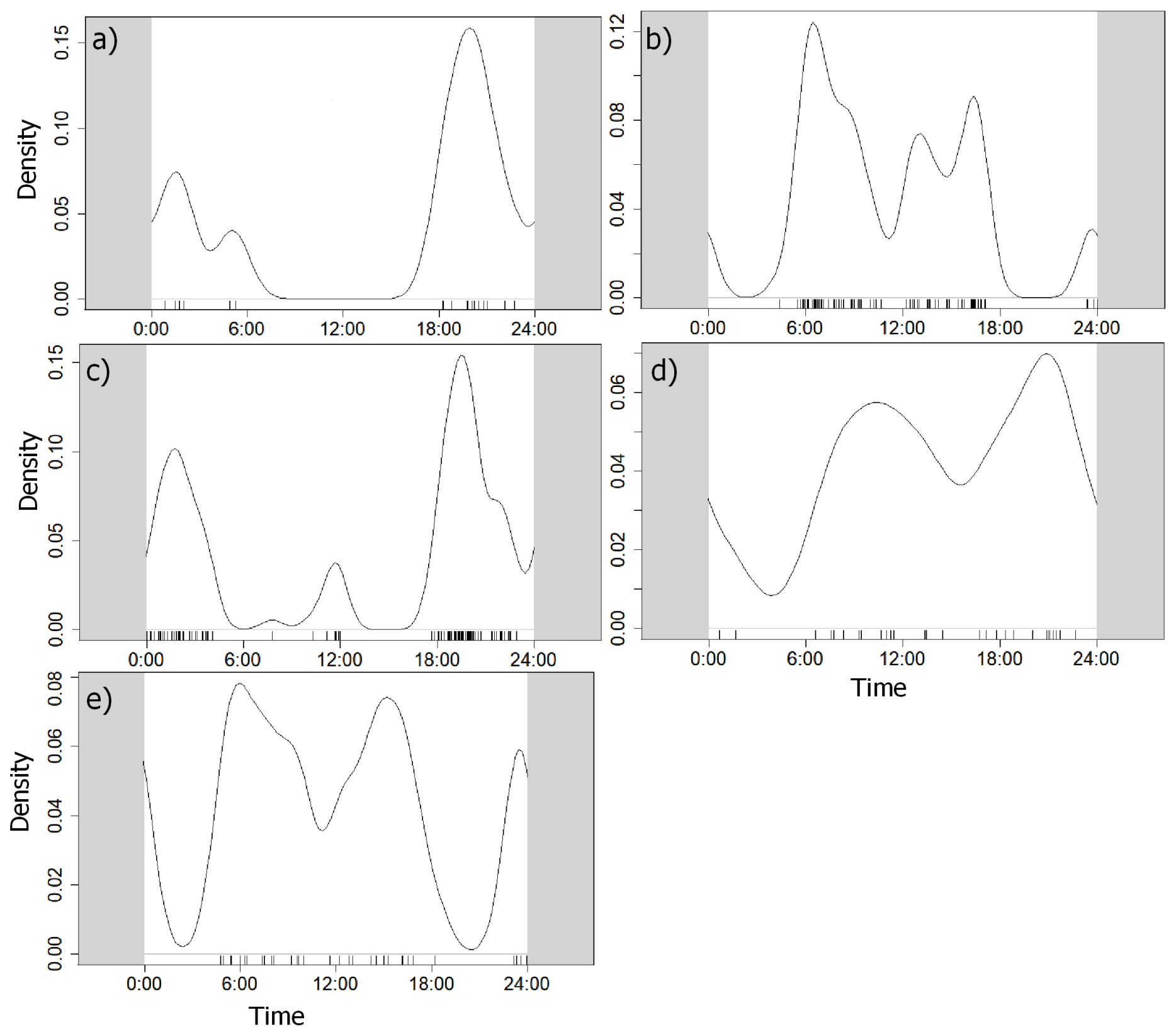

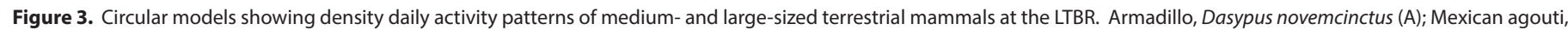
Dasyprocta mexicana (B); Agouti, Cuniculus paca (C); Collared peccary, Dicotyles angulatus (D), and Coati, Nasua narica (E).

whose $95 \% \mathrm{Cl}$ overlapped. Finally, when the most common species were weighted more heavily, El Gavilán had the highest diversity (8.91 effective species), followed by La Encrucijada (6.12), Los Chimalapas (5.90), LTBR (4.69), Tolistoque (4.44), and Los Petenes (3.61). Only the order-2 diversity of El Gavilán was significantly different from those of the other areas; there were no significant differences between LTBR, Tolistoque, and Los Petenes, nor between Los Chimalapas and La Encrucijada (Figure 4).

Trapping rates. The comparison of trapping rates across the different study areas showed that the trapping rates of C. paca and D. mexicana were noticeably higher in the LTBR than in the other study sites. These rates almost doubled those observed at Los Chimalapas and Los Petenes - the areas where these species had the second-highest trapping rates. The trapping rates of $D$. novemcinctus and T. mexicana were also highest in the LTBR, although these were only slightly higher than in the other study sites. The trapping rates of $D$. angulatus and $S$. aureogaster in the LTBR were the second-highest among the other study sites (Figure 5).

\section{Discussion}

The 13 species recorded in our study had all been reported previously for the LTBR (Flores-Martínez et al. 2014; GonzálezChristen and Coates 2019). González-Christen and Coates (2019) recently concluded, based on a review of the relevant literature, that 32 species of medium- and large-sized terrestrial mammals (i.e., excluding mice, shrews, and bats) have been recorded in the region. Thus, our study recorded 41.6 $\%$ of all species in this group reported previously for LTBR. 
The species richness recorded in our study at LTBR was lower than a previous study, which recorded 17 species using the same methods (Flores-Martínez et al. (2014). The species not recorded in our study were Sciurus deppei, Herpailurus yagouaroundi, Galictis vittata, Procyon lotor, Conepatus semistriatus, and Philander opossum. Further, Flores-Martínez et al. (2014) did not record S. aureogaster nor M. temama. The differences in the species number and identities between our study and Flores-Martínez et al. (2014) may result from the fact that the latter was conducted exclusively in the Los Tuxtlas Biological Station. It is likely that the Los Tuxtlas Biological Station serves as a refuge for medium and large-sized terrestrial mammals of the region and harbors a higher number of animal species than other areas in the region (Laurance et al. 2012; Rodríguez and Domínguez 2017). For example, some rare or cryptic mammal species were recorded just once or twice by Flores-Martínez et al. (2014; e. g., G. vittata and $P$. opossum) or only occasionally (e. g., H. yagouaroundi and $P$. lotor, eight records each). On the other hand, we were unable to record some of the species frequently recorded by Flores-Martínez et al. (2014), such as S. deppei (188 records) and C. semistriatus (27 records). S. aureogaster and M. temama, which were not recorded by Flores-Martínez et al. (2014), occurred in low abundance and were recorded only occasionally in our study. It is important to highlight the absence of large-sized terrestrial mammals such as Panthera onca, Puma concolor, Odocoileus virginianus, and
Tayassu pecari, which are known to (historically) occur in the region (Estrada et al. 1994; Dirzo and Mendoza 2007).

Cuniculus paca, D. mexicana, N. narica, and D. angulatus were the species with the highest trapping rate in our study (Figure 2). This is consistent with previous studies documenting $D$. mexicana, N. narica, and C. paca as the species most frequently recorded in this region (Flores-Martínez et al. 2014). Further, in other regions of the State of Veracruz, the species showing the highest trapping rates were $D$. marsupialis, D. novemcinctus, C. paca, and D. mexicana (Gallina and González-Romero 2018). The low trapping rates of another species observed in our study can be explained by the fact that species such as M. temama and L. wiedii have become locally rare due to habitat loss and fragmentation. These species have shown higher trapping rates in other regions that are better conserved or have suffered less anthropogenic impact (Muñoz-Vazquez and GallinaTessaro 2016; Pérez-Irineo and Santos-Moreno 2016 a, b). Other species, such as $L$. pardalis, require sufficient prey availability and areas for dispersal (Pérez-Irineo and SantosMoreno 2014).

Diversity indices. The estimated order-0 diversity (species richness) for LTBR was slightly above the observed number of species (13.99 vs. 13 species, respectively). Order-0 diversity for LTBR was lower compared to values reported for other study sites in southeast Mexico; it was only higher than order-0 diversity at El Gavilán. Although the lowest order-0 diversity was recorded at El Gavilán, this

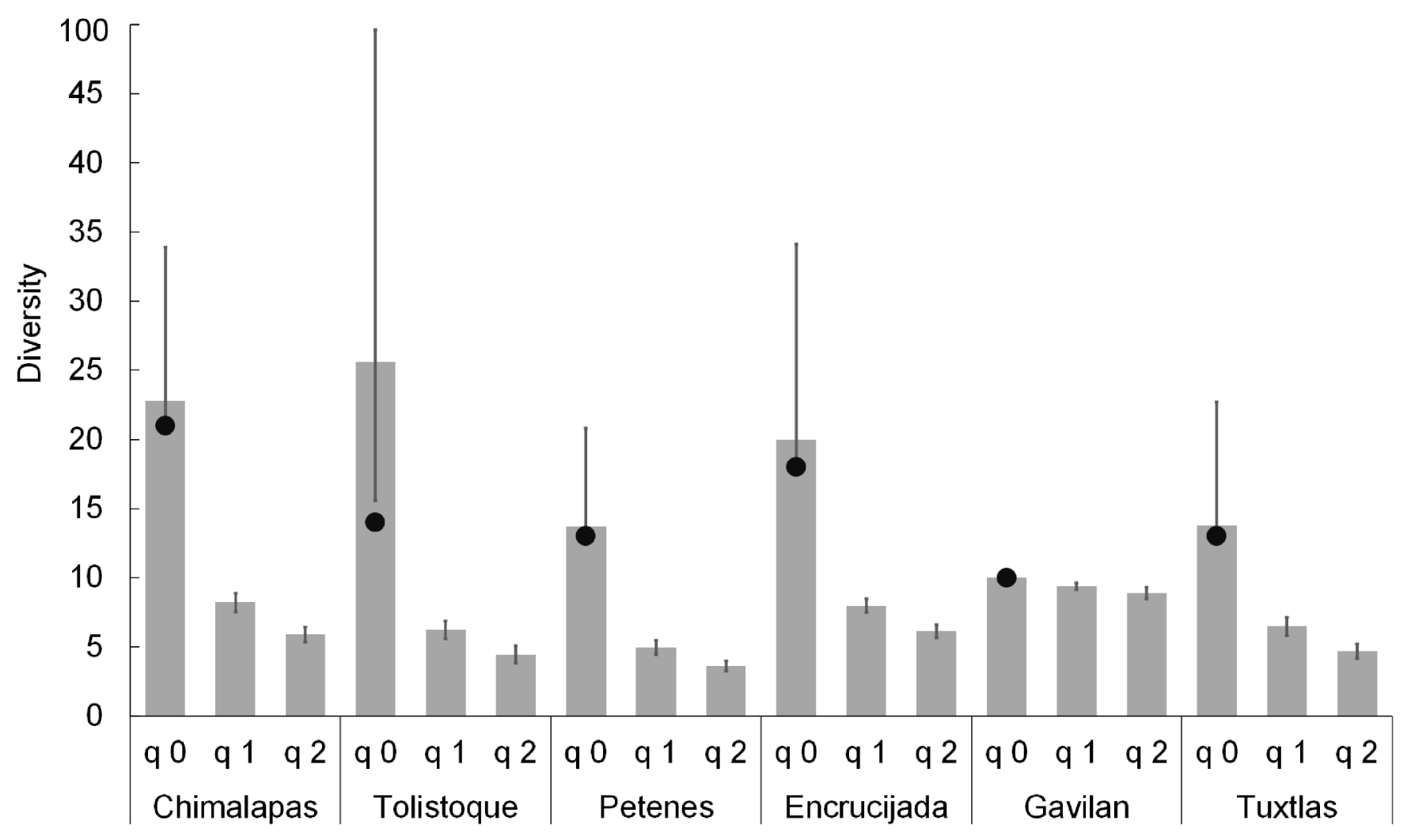

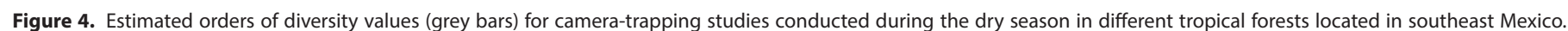

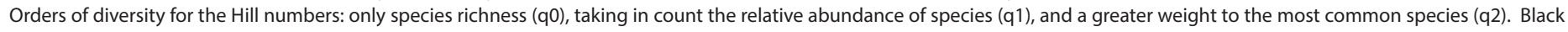
dots indicate the observed species richness; $95 \%$ confidence intervals are indicated by vertical lines. 


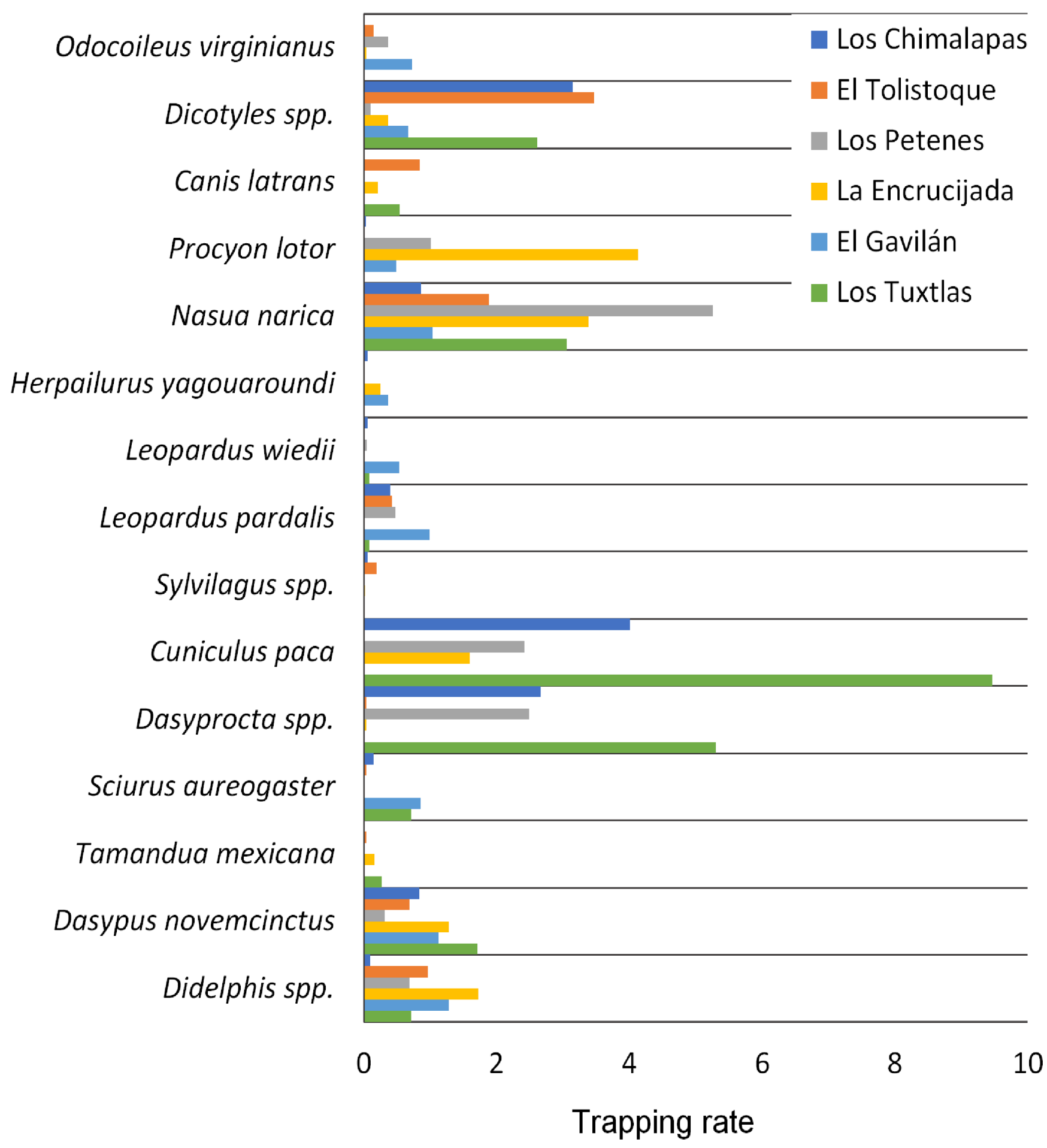

Figure 5. Frequency of trapping rates for medium- and large-sized terrestrial mammals recorded at six study sites located in southeastern Mexico. See Methods for details.

site had higher values for the other diversity values, which include the relative abundance of species into account (order 1), or place a higher weight on the dominant species (order 2). The high order-1 and order-2 diversity values at EI Gavilán reflect the existence of a more diverse community with a more even distribution of abundances (Moreno et al. 2011). For instance, the difference in recording frequency between the species most and least frequently recorded at El Gavilán was $28.9 \%$, whereas this difference was $0.4 \%$ at
Los Chimalapas, $1.1 \%$ at Tolistoque, $1.0 \%$ at Los Petenes, $0.5 \%$ at La Encrucijada, and $0.9 \%$ at Los Tuxtlas (Figure 4). The protection status of El Gavilán as an area voluntarily dedicated to conservation might have contributed to these high diversity values (Buenrostro-Silva et al. 2020).

Los Chimalapas and La Encrucijada study sites also showed high diversity values. Although Los Chimalapas is not included in any formal protection scheme, this area comprises a vast extension of almost continuous tropical rainfor- 
est of difficult access, and holds a low human population density, which favors the persistence of medium and large-sized terrestrial mammals (Lira-Torres and Briones-Salas 2011). In comparison, La Encrucijada is a federally protected area; its protection status and diverse vegetation cover, ranging from mangrove swamps to deciduous tropical forests, favors the presence, abundance, and diversity of mid-sized and large mammals (Hernández-Hernández et al. 2018).

The lowest order- 1 and order- 2 diversity indices were recorded at El Tolistoque and Los Petenes study sites (Figure 4). El Tolistoque is an area that, out of a social initiative, has been voluntarily dedicated to conservation, thus favoring the preservation of habitats and persistence of the local fauna (Cortés-Marcial and Briones-Salas 2014). Nevertheless, hunting is a common practice around this area, thus undermining its aim of conserving biodiversity (CortésMarcial 2009). Los Petenes are composed mainly of Petenes, which are plant formations that are key for mammals in the Yucatán Peninsula because they supply water and food, and which might be limited in the contiguous tropical dry forest. However, their restricted area might explain the lack of records and the low trapping rate of medium and largesized terrestrial mammals that are common in the Yucatan Peninsula (Hernández-Pérez et al. 2015). Although LTBR is a federally protected area, it has historically undergone deforestation resulting in habitat loss and fragmentation, undermining the diversity of medium- and large-sized terrestrial mammals (Dirzo and Mendoza 2007), which was evident in the recorded intermediate values of the order-1 and order-2 diversity indices (Figure 4).

Further, Ruiz-Gutiérrez et al. (2020) studied medium and large-sized terrestrial mammals in eight landscapes on the Sierra Madre del Sur mountain range in the State of Guerrero, Mexico. They estimated species richness ranging from 13 to 19 species, and an order-1 diversity index from 6 to 12 effective species, for the eight landscapes. These ranges are consistent with those reported in the studies reviewed herein. Ruiz-Gutiérrez et al. (2020) found a positive relationship between the order-1 diversity index and variations in elevation and ecological integrity of the landscape. These findings agree with the close relationship found by GalindoAguilar et al. (pers. comm.) between the ecological integrity of the landscape and defaunation rates of medium- and large-sized terrestrial mammals in Mexican tropical forests. Both analyses explain why well-preserved areas such as Los Chimalapas and La Encrucijada show higher diversity values relative to more degraded sites.

Activity patterns. The activity patterns exhibited by five species from the LTBR are consistent with those reported elsewhere. A diurnal activity pattern has been described for N. narica and D. mexicana (Lira-Torres and Briones-Salas 2011; Hernández-SaintMartín et al. 2013; HernándezHernández et al. 2018; Buenrostro et al. 2020), a nocturnal and crepuscular pattern for D. novemcinctus and C. paca (Harmsen et al. 2011; Lira-Torres and Briones-Salas 2011; Cortés-Marcial and Briones-Salas 2014; Arroyo-Arce et al.
2017; Hernández-Hernández et al. 2018), and diurnal and crepuscular with some nocturnal activity for Dicotyles spp. (Harmsen et al. 2011; Lira-Torres and Briones-Salas 2011; Hernández-SaintMartín et al. 2013; Cortés-Marcial and Briones-Salas 2014; Buenrostro et al. 2020). These results show that species retain their overall circadian rhythm regardless of the type of habitat or location and suggest a conservatism of this trait (de Oliveira et al. 2016). However, other detailed studies have shown that species can vary their activity patterns in response to environmental changes, such as natural vs. artificial lighting conditions (Harmsen et al. 2011; Michalski and Norris 2011; Mendes et al. 2020) or the landscape configuration (Norris et al. 2010). Further studies across the landscapes within a disturbance gradient in Mexican forests are needed to investigate potential impacts on circadian rhythms of terrestrial mammals.

Conservation implications. Neotropical forests are ecosystems harboring a high number of species (SánchezColón et al. 2009; Reynoso et al. 2017). However, these ecosystems have suffered from rampant deforestation over the last decades with a significant negative impact on biodiversity. Several studies have shown the adverse effects on vertebrate diversity, including terrestrial mammals (Dirzo and Mendoza 2007; Laurance et al. 2012). Protected areas and biological field stations have served as refuges for numerous plant and animal species (Laurance et al. 2012; FloresMartínez et al. 2014; Rodríguez and Domínguez 2017). Los Tuxtlas Biological Station has been the focus of an impressive research effect on studies of biodiversity for several decades (Estrada et al. 1994; González-Soriano et al. 1997; Reynoso et al. 2017; Gallina and González-Romero 2018; González-Christen and Coates 2019). Further studies aimed at inventorying the flora and fauna of Mexican tropical forests are of high relevance to produce basic information on their conservation status.

The loss of medium- and large-sized terrestrial mammals has major negative consequences on ecosystem dynamics as it might lead to an increase of small mammal population densities with a potential change in the rates of seed predation and seedling recruitment in tropical forest (SánchezCordero and Fleming 1993; Kurten 2013; Galetti et al. 2015; Carreira et al. 2020). In the case of the LTBR, we were unable to record large-sized mammals such as $P$. concolor, $P$. onca, or T. pecari. Restoring the continuity of this tropical forest is necessary to facilitate the movement of individuals of these species away from areas inhabited by human populations.

Our study showed that protected areas created as a result of community-based (Los Chimalapas, El Tolistoque, and El Gavilán) or government (La Encrucijada, Los Petenes, and LTBR) initiatives are key for conserving medium- and large-sized terrestrial mammals. Community-based conservation initiatives are promoted by local communities with support from non-governmental organizations, aiming to conserve biodiversity by adopting a respectful and inclusive approach (Briones-Salas et al. 2016). Therefore, community-based conservation initiatives should be 
encouraged and supported to further advance biodiversity conservation in southern Mexico.

\section{Acknowledgments}

We thank the LTBR office of the Comisión Nacional de Áreas Naturales Protegidas, the PROVICOM monitoring crew, and the livestock ranching association of the municipality of Pajapam, Veracruz for providing support. We also thank R. Gómez-Toledo and E. Galindo-Aguilar for their invaluable support in planning and collecting data. G. Pérez-Irineo contributed with fruitful ideas in an early version of the manuscript. MCL acknowledgement the support of EDIIPN. M. E. Sánchez-Salazar helped in English editing.

We are honored to dedicate this contribution to Professor David J. Schmidly. David has been instrumental for the development of mammalogy in Mexico. He has trained and graduated dozens of Mexican students, which in turn, have trained and graduated dozens of Mexican students. The starting point of this virtuous circle has been David. For me (Víctor), David has been a mentor in my academic career. I have many anecdotes with David, but certainly that first meeting in Mazatlán many, many years ago marked me as a mammalogist. We should commit ourselves to continue the legacy of David. For decades, he has been promoting the study of the natural history of mammals. We should do that more often. Gracias querido David por tus enseñanzas, tu amistad y tu compromiso hacia México! Un abrazo muy fuerte de tu amigo Víctor.

\section{Literature Cited}

Arroyo-Arce, S., I. Thomson, C. Fernández, and R. Salom-Pérez. 2017. Relative abundance and activity patterns of terrestrial mammals in Pacuare Nature Reserve, Costa Rica. Cuadernos de Investigación UNED 9:15-21.

Briones-Salas, M., M. C., Lavariega, M. Cortés-Marcial, A. G. Monroy-Gamboa, and C. A, Masés-García. 2016. Iniciativas de conservación para los mamíferos de Oaxaca, México. Pp. 329366, in Riqueza y Conservación de los Mamíferos en México a Nivel Estatal (Briones-Salas, M., Y. Hortelano-Moncada, G. Magaña-Cota, G. Sánchez-Rojas, and J. E. Sosa-Escalante, eds.). Instituto de Biología, Universidad Nacional Autónoma de México, Asociación Mexicana de Mastozoología A. C. y Universidad de Guanajuato. Mexico City, Mexico.

Bogoni, J. A., C. A Peres, K. M. P. M. B. Ferraz. 2020. Extent, intensity and drivers of mammal defaunation: a continental-scale analysis across the Neotropics. Scientific Reports 10:14750.

Buenrostro, A., O. Sánchez, and J. García-Grajales. 2020. Daily activity patterns and relative abundance of medium and large mammals in a communal natural protected area on the central coast of Oaxaca, Mexico. International Journal of Biodiversity and Conservation 12:159-168.

Carreira, D. C., W. Dáttilo, D. L. Bruno, A. R. Percequillo, K. M. P. B. Ferraz, AND M. Galetti. 2020. Small vertebrates are key elements in the frugivory networks of a hyperdiverse tropical forest. Scientific Report 10:1-11.

Canale, G. R., C. A. Peres, C. E. Guidorizzi, C. A. F. Gatto, and M. C. M. Kierulff. 2012. Pervasive defaunation of forest rem- nants in a tropical biodiversity hotspot. PloS One 7:e41671. Ceballos, G., H. Zarza, C. Chávez, and J. F. González-Maya. 2016. Ecology and conservation of jaguars in Mexico, state of knowledge and future challenges. Pp. 273-289, in Tropical Conservation: Perspectives on Local and Global Priorities (Aguirre, A. A. and R. Sukumar, eds.). Oxford: Oxford University Press. New York, United States.

Challenger, A., And R. Dirzo. 2009. Factores de cambio y estado de la biodiversidad. Pp. 37-73, in Capital Natural de México: Vol. II (Dirzo, R., R. González, and I. March, eds.). Comisión Nacional para el Conocimiento y Uso de la Biodiversidad. Mexico City, Mexico.

Chao, A., AND L. Jost. 2015. Estimating diversity and entropy profiles via discovery rates of new species. Methods in Ecology and Evolution 6:873-882.

ChaO, A., K. H. MA, T. C. Hsieh, and C. H. Chiu. 2016. User's guide for online program Spade $\mathrm{R}$ (Species-richness prediction and diversity estimation in R). Institute of Statistics National Tsing Hua University, Taiwan. Available at http://chao. stat.nthu.edu.tw/wordpress/software_download/softwarespader_online/. Accessed on 30 August 2020.

Comisión Nacional de Áreas Naturales Protegidas (CONANP). 2006. Programa de conservación y manejo de la Reserva de la Biosfera Los Tuxtlas. 1ra Edición. Comisión Nacional de Áreas Naturales Protegidas, Secretaria de Medio Ambiente y Recursos Naturales. Mexico City, Mexico.

Cortés-Marcial, M. 2009. Diversidad de mamíferos medianos y grandes en dos sitios con diferente grado de conservación en la Venta, Juchitán, Oaxaca. Tesis de Maestría, Instituto Politécnico Nacional.

Cortés-Marcial, M., and M. Briones-Salas. 2014. Diversidad, abundancia relativa y patrones de actividad de mamíferos medianos y grandes en una selva seca del Istmo de Tehuantepec, Oaxaca, México. Revista de Biología Tropical 62:1433-1448.

de Oliveira, M. L., P. H. de Faria Peres, A. Vogliotti, F. Grotta-Neto, A. D: K. de Azevedo, J. F. Cerveira, G. B. do Nascimiento, N. P. Peruzzi, J. Carranza, and J. M. B. Duarte. 2016. Phylogenetic signal in the circadian rhythm of morphologically convergent species of Neotropical deer. Mammalian Biology 81:281-289.

Dirzo, R., AND E. Mendoza. 2007. Size-related differential seed predation in a heavily defaunated neotropical rain forest. Biotropica 39:355-362.

Estrada, A., R. Coates-Estrada, and D. Jr. Meritt. 1994. Non flying mammals and landscape changes in the tropical rain forest region of Los Tuxtlas, Mexico. Ecography 17:229-241.

Ferguson, S. H., and S. Larivière. 2002. Can comparing life histories help conserve carnivores? Animal Conservation 5:1-12.

Flores-Martínez, J. J., R. I. Coates, V. Sánchez-Cordero, and V. J. Mendieta. 2014. Mamíferos terrestres de la Estación de Biología Tropical de los Tuxtlas. Revista Digital Universitaria 15:1-10.

Flores-Villela, O., and U. O. García-Vázquez. 2014. Biodiversidad de reptiles en México. Revista Mexicana de Biodiversidad 85:467-475.

Galleti, M., R. S. Bovendorp, and R. Guevara. 2015. Defaunation of large mammals leads to an increase in seed predation in the Atlantic forests. Global Ecology and Conservation 3:824-830. 
Gallina, S., And A. GonzÁlez-Romero. 2018. La conservación de mamíferos medianos en dos reservas ecológicas privadas de Veracruz, México. Revista Mexicana de Biodiversidad 89:1245-1254.

García, A. E. 2004. Modificación al sistema de clasificación climática de Köppen. Instituto de Geografía, UNAM.

Garmendia, A., V. Arroyo-Rodríguez, A. Estrada, E. Naranjo, and K. E. Stoner. 2013. Landscape and patch attributes impacting medium- and large-sized terrestrial mammals in a fragmented rain forest. Journal of Tropical Ecology 29:331-344.

Gerez-Fernández, P., And M. del R. Pineda-López. 2011. Los bosques de Veracruz en el contexto de una estrategia estatal REDD+. Madera y Bosques 17:7-27.

González-Soriano, S., R. Dirzo, And V. Richard. 1997. Historia natural de Los Tuxtlas. Universidad Nacional Autónoma de México, Instituto de Biología. Mexico.

González-Christen, A., And C. A. Delfín-Alfonso. 2016. Los mamíferos terrestres de Veracruz y su protección. Pp. 499534 in Riqueza y Conservación de los Mamíferos en México a Nivel Estatal (Briones-Salas, M., Y. Hortelano-Moncada, G. Magaña-Cota, G. Sánchez-Rojas, and J. E. Sosa-Escalante, eds.). Instituto de Biología, Universidad Nacional Autónoma de México, Asociación Mexicana de Mastozoología A. C. and Universidad de Guanajuato. Mexico.

González-Christen, A., And R. Coates. 2019. Los mamíferos no voladores de la región de Los Tuxtlas, Veracruz, México. Revista Mexicana de Biodiversidad 90:e902580.

González-Salazar, C., E. Martínez-Meyer, and G. López-Santiago. 2014. A hierarchical classification of trophic guilds for North American birds and mammals. Revista Mexicana de Biodiversidad 85:931-941.

Gotell, N. J., And A. Chao. 2013. Measuring and estimating species richness, species diversity, and biotic similarity from sampling data. Pp. 195-211 in Encyclopedia of Biodiversity (Levin, S. A., ed.). Academic Press. EE. UU.

Gutiérrez-García, G., AND M. Rıcker. 2011. Climate and climate change in the region of Los Tuxtlas (Veracruz, Mexico): A statistical analysis. Atmósfera 24:347-373.

Harmsen, B. J., R. J. Foster, S. C. Silver, L. E. Ostro, and C. P. DonCASTER. 2011. Jaguar and puma activity patterns in relation to their main prey. Mammalian Biology 76:320-324.

Hernández-Hernández, J. C., C. Chávez, and R. List. 2018. Diversidad y patrones de actividad de mamíferos medianos y grandes en la Reserva de la Biosfera La Encrucijada, Chiapas, México. Revista de Biología Tropical 66: 634-646.

Hernández-Pérez, E., R. Reyna-Hurtado, G. Castillo Vela, M. Sanvicente López, and J. F. Moreira-Ramírez. 2015. Fototrampeo de mamíferos terrestres de talla mediana y grande asociados a petenes del noroeste de la península de Yucatán, México. Therya 6:559-574.

Hernández-SaintMartín, A. D., O. C. Rosas-Rosas, J. PalacioNúñez, L. A. Tarango-Arámbula, F. Clemente-Sánchez, and A. L. Hoogesteisn. 2013. Activity patterns of jaguar, puma and their potential prey in San Luis Potosí, Mexico. Acta Zoológica Mexicana (n. s.) 29:520-533.

Instituto Nacional de Estadística y Geografía (INEGI). 2015. Mapa vectorial de uso de suelo y vegetación de México, serie VI, escala 1:250,000. Instituto Nacional de Estadística y Geografía. San Luis Potosí, Mexico.
Jenks, K., P. Chanteap, K. Damrongchainarang, P. Cutter, P. Cutter, T. Redford, A. J. Lynan, J. Howard, ANd P. Leimgruber. 2011. Using relative abundance indices from camera-trapping to test wildlife conservation hypotheses - an example from Khao Yai National Park, Thailand. Tropical Conservation Science 4:113-131. Jost, L. 2006. Entropy and diversity. Oikos 113:363-375.

Jost, L., AND J. A. González-Oreja. 2012. Midiendo la diversidad biológica: Más allá del índice de Shannon. Acta Zoológica Lilloana 56:3-14.

Kurten, E. L. 2013. Cascading effects of contemporaneous defaunation on tropical forest communities. Biological Conservation 163:22-32.

Laurance, W. F., Et Al. 2012. Averting biodiversity collapse in tropical forest protected areas. Nature 489:290-294.

Laurance, W. F., Laurance, S., y D. Hilbert. 2008. Long-term dynamics of a fragmented rainforest mammal assemblage. Conservation Biology 22:1154-1164.

Lavariega, C. M., A. J. Ríos-Solís, J. J. Flores-Martínez, E. R. Galindo-Aguilar, V. Sánchez-Cordero, S. Juan-Albino, and E. Soriano-Martínez. 2020. Community-Based monitoring of Jaguar (Pantera onca) in the Chinantla Region, Mexico. Tropical Conservation Science 13:1-16.

Lira-Torres, I., ANd M. Briones-Salas. 2011. Impacto de la ganadería extensiva y cacería de subsistencia sobre la abundancia relativa de mamíferos en la Selva Zoque, Oaxaca, México. Therya 2:217-244.

LiRA-Torres, I., AND M. Briones-Salas. 2012. Abundancia relativa y patrones de actividad de los mamíferos de los Chimalapas, Oaxaca, México. Acta Zoológica Mexicana (n. s.) 28:566-585.

MagurRan, A. E. 2004. Measuring biological diversity. Blackwell Science Ltd. Oxford, United Kingdom.

Mas, J.-F., A. Velázquez, and S. Couturier. 2009. La evaluación de los cambios de cobertura/uso del suelo en la República Mexicana. Investigación Ambiental 1:23-39.

Mendes, C. P., D. Carreira, F. Pedrosa, G. Beca, L. Lautenschlager, P. AkkaWı, W. Berce, K. M. P. M. B. Ferraz, and M. Galetti. 2020. Landscape of human fear in Neotropical rainforest mammals. Biological Conservation 241:1-8

Meredith, M. 2018. Package "overlap" Title Estimates of Coefficient of Overlapping for Animal Activity Patterns.

Michalski, F., And C. A. Peres. 2007. Disturbance-mediated mammal persistence and abundance-area relationships in Amazonian forest fragments. Conservation Biology 21:1626-1640.

Michalskı, F., AND D. NorRIs. 2011. Activity pattern of Cuniculus paca (Rodentia: Cuniculidae) in relation to lunar illumination and other abiotic variables in the southern Brazilian Amazon. Zoologia (Curitiba) 28:701-708.

Monroy-Vilchis, O., M. M. Zarco-González, C. Rodríguez-Soto, L. Soria-Díaz, AND V. Urios. 2011. Fototrampeo de mamíferos en la Sierra Nanchititla, México: abundancia relativa y patrón de actividad. Revista de Biología Tropical 59:373-383.

Moreno, C. E., F. Barragán, E. Pineda, And N. P. Pavón. 2011. Reanálisis de la diversidad alfa: alternativas para interpretar y comparar información sobre comunidades ecológicas. Revista Mexicana de Biodiversidad 82:1249-1261.

Morrone, J. J. 2019. Regionalización biogeográfica y evolución biótica de México: encrucijada de la biodiversidad del Nuevo Mundo. Revista Mexicana de Biodiversidad 90:e902980. 
Muñoz-Vazquez, B., And S. Gallina-Tessaro. 2016. Influence of habitat fragmentation on abundance of Mazama temama at different scales in the cloud forest. Therya 7:77-87.

Navarro-Sigüenza, A. G., M. F. Rebón-Gallardo, A. GordilloMartínez, A. T. Peterson, H. Berlanga-García, and L. A. SánchezGonzález. 2014. Biodiversidad de aves en México. Revista Mexicana de Biodiversidad 85:476-495.

Negrões, N., E. Revilla, C. Fonseca, A. M. Soares, A. T. A. Jácomo, AND L. Silveira. 2011. Private forest reserves can aid in preserving the community of medium and large-sized vertebrates in the Amazon arc of deforestation. Biodiversity and Conservation 20:505-518.

Norris, D., F. Michalski, And C. A. Peres. 2010. Habitat patch size modulates terrestrial mammal activity patterns in Amazonian forest fragments. Journal of Mammalogy 91:551-560.

O'Connell, A. F., J. D. Nichols, and K. U. Karanth (eds.). 2010. Camera traps in animal ecology: methods and analyses. Springer Science \& Business Media. New York, U.S.A.

Parra-Olea, G., O. Flores-Villela, and C. Mendoza-Almeralla. 2014. Biodiversidad de anfibios en México. Revista Mexicana de Biodiversidad 85:460-466.

Pérez-Irineo, G., and A. Santos-Moreno. 2010. Diversidad de una comunidad de mamíferos carnívoros del noreste de Oaxaca, México. Acta Zoológica Mexicana (n. s.) 26:721-736.

Pérez-Irineo, G., And A. Santos-Moreno. 2013. Riqueza de especies y gremios tróficos de mamíferos carnívoros en una selva alta del sureste de México. Therya 4:551-564.

Pérez-Irineo, G., And A. Santos-Moreno. 2014. Density, distribution, and activity of the ocelot Leopardus pardalis in Southeast Mexican rainforest. Revista de Biología Tropical 62:1421-1432.

Pérez-Irineo, G., And A. Santos-Moreno. 2016a. Abundance and activity patterns of medium-sized felids (Felidae, Carnivora) in Southeastern Mexico. The Southwestern Naturalist 61:33-39.

Pérez-Irineo, G., and A. Santos-Moreno. 2016b. Abundance, herd size, activity pattern and occupancy of ungulates in Southeastern Mexico. Animal Biology 66:97-109.

QGIS Development Team. 2017. QGIS Geographic Information System. Open Source Geospatial Foundation Project. Available at http://qgis.osgeo.org. Accessed at May 2020.

Ramírez-Pulido, J., N. González-Ruiz, A. L. Gardner, and J. ArRoyo-Cabrales. 2014. List of recent land mammals from Mexico. Special Publications Museum of Texas Tech University 63:1-69.

Reynoso, H. V., I. R. Coates, And C. L. M. Vázquez. 2017. Avances y perspectivas en la investigación de los bosques tropicales y sus alrededores: La región de Los Tuxtlas. Universidad Nacional Autónoma de México, Instituto de Biología. Mexico.

Robinson, W. D. 1999. Long-term changes in the avifauna of Barro Colorado Island, Panama, a tropical forest isolate. Conservation Biology 13:85-97.

Rodríguez, L. E., ANd A. Y. Domínguez. 2017. Importancia de las estaciones biológicas en las Áreas Naturales Protegidas: el significado de Los Tuxtlas. Pp. 53-64 in Avances y perspectivas en la investigación de los bosques tropicales y sus alrededores: La región de Los Tuxtlas (Reynoso, H. V., I. R. Coates, and C. L. M. Vázquez, eds.). Universidad Nacional Autónoma de México, Instituto de Biología. Mexico.
Roemer, G. W., M. E. Gompper, and B. Van Valkenburgh. 2009. The ecological role of the mammalian mesocarnivore. BioScience 59:165-173.

Ruiz-Gutiérrez, F., C. Chávez, G. Sánchez-Rojas, C. E. Moreno, C. González-Salazar, B. O. Ruiz-Gutiérrez, and R. Torres-Bernal. 2020. Mamíferos medianos y grandes de la Sierra Madre del Sur de Guerrero, México: evaluación integral de la diversidad y su relación con las características ambientales. Revista Mexicana de Biodiversidad 91:913168.

Sánchez-Colón, S., A. Flores-Martínez, A. Cruz-Leyva, and A. VeLÁZquEz. 2009. Estado y transformación de los ecosistemas terrestres por causas humanas. Pp. 75-129 in Capital natural de México: Vol. II (Dirzo, R., R. González, and I. March, eds.). Comisión Nacional para el Conocimiento y Uso de la Biodiversidad. Mexico.

Sánchez-Cordero, V., And T. H. Fleming. 1993. Ecology of tropical heteromyids. Ecología de los heteromyídos tropicales. American Society of Mammalogists. Special Publication 10:596-617. Sánchez-Cordero, V., F. Botello, J. J. Flores-Martínez, R. A. Gómez-Rodríguez, L. Guevara, G. Gutiérrez-Granados, and Á. RodríGUez-Moreno. 2014. Biodiversidad de Chordata (Mammalia) en México. Revista Mexicana de Biodiversidad 85:496-504.

Secretaría de Medio Ambiente y Recursos Naturales (SEMARNAT). 2016. Prontuario Estadístico y Geográfico de las Áreas Naturales Protegidas de México. Mexico.

Sigel, B. J., T. W. Sherry, And B. E. Young. 2006. Avian community response to lowland tropical rainforest isolation: 40 years of change at La Selva Biological Station, Costa Rica: Avian community response to forest isolation. Conservation Biology 20:111-121.

Sollmann, R. 2018. A gentle introduction to camera-trap data analysis. African Journal of Ecology 56:740-749.

Velázquez, A., J. F. Mas, J. R. Díaz Gallegos, R. Mayorga Saucedo, P. C. Alcántara, R. Castro, T. Fernández, G. Bocco, E. Ezcurra, AND J. L. Palacio. 2002. Patrones y tasas de cambio de uso del suelo en México. Gaceta Ecológica 62: 21-37.

Vega-Vela, V., C. A. Munoz-Robles, E. Rodríguez-Luna, J. C: López-Acosta, and R. Serna-Lagunes. 2018. Analysis of landscape fragmentation in the Los Tuxtlas Biosphere Reserve, Veracruz, México. Ecosistemas y Recursos Agropecuarios 5:227-238.

Von Thaden, J. J., J. Laborde, S. Guevara, and P. Mokondoko-DelGADILLO. 2020. Dinámica de los cambios en el uso del suelo y cobertura vegetal en la Reserva de la Biosfera Los Tuxtlas (2006-2016). Revista Mexicana de Biodiversidad 91:e913190.

Associated editor: Lisa and Robert Bradley

Submitted:December 9, 2020; Reviewed: March12, 2021;

Accepted:March 30, 2021; Published on line: May 28, 2021. 